\title{
Lesion detection in conventional gamma camera, SPECT and SPECT / CT systems: Phantom study
}

Konvansiyonel ve SPECT/BT sistemlerinde Fantom çalışması

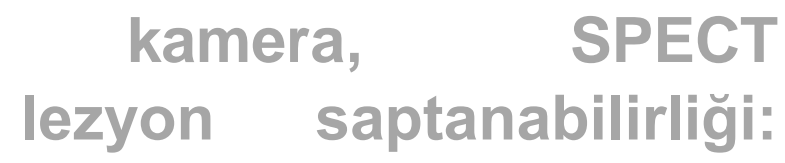

kamera, SPECT

gama lezyon saptanabilirliği:

Yağmur İdill Ulusoy ${ }^{1}$, Mert Karagöz ${ }^{1}$,Nami Yeyin ${ }^{1}$ Mustafa DEMIIR ${ }^{1}$

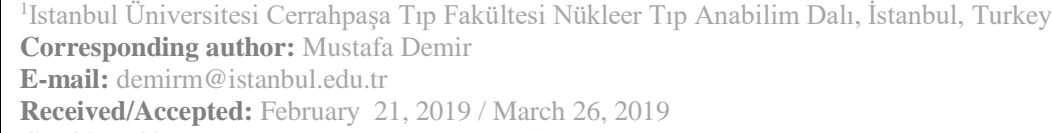

\section{SUMMARY}

Objective: It was aimed to create special phantom to be used for benchmarking the lesion detectability of planar, SPECT and SPECT / CT systems by computing the corresponding contrast (C) and contrast / noise ratio (CNR) of the lesions with different activity concentrations.

Method: In the study, the phantom was equiped with with four lesions filled with radioiodine $\left({ }^{131} \mathrm{I}\right)$. The phantom's planar images were acquired by two different gamma cameras with small field of view (SFOV) and large field of view (LFOV). Tomographic images were obtained from SPECT and SPECT / CT scans. Contrast (C) and contrast-to-noise ratio (CNR) were calculated by delineating areas of interest (ROI) over the tubes and background with different activity concentrations in the phantom.

Results: As the camera's field of view increased, the related contrast and CNR values increased partially. Contrast and CNR values of SPECT and SPECT / CT images were significantly higher than planer images.

Conclusions: It was found that the superior lesion detectability might be achieved by SPECT or SPECT / CT (AC) imaging techniques.

Keywords: Scintigraphic imaging, SPECT, SPECT/CT, Image quality, Contrast to noise ratio.

\section{ÖZET}

Amaç: Klinik çalışmalara uygun bir fantom dizayn edilmesi, fantomun planar, SPECT ve SPECT/BT sintigrafik görüntülerinde lezyon saptanabilirlik değerlerinin belirlenmesi planlandı. Fantomda eşit hacimde olup farklı aktivite konsantrasyonlarına sahip lezyonların kontrast (C) ve kontrast/gürültü (CNR) belirlenerek değerlendirilmesi amaçlandı. Yöntem: Çalışmada farklı aktivite konsantrasyonlarına sahip dört farklı lezyonu olan bir fantom kullanıldı. Fantomun planer sintigrafik görüntüleri küçük görüş alanı (SFOV) ve büyük görüş alanı olan 2 farklı gama kamerada alındı. Tomografik görüntüler SPECT ve SPECT/BT cihazlarında alındı. Fantomdaki farklı aktivite konsantrasyonlarına sahip tüplerden ve zeminden ilgi alanları (ROI) çizilerek kontrast (C) ve kontrast-gürültü oranı (CNR) hesaplandı.

Bulgular: Kamera görüş açısı büyüdükçe C ve CNR değerlerinin kısmen arttı̆̆ı gözlendi. SPECT ve SPECT/BT görüntülerinin C ve CNR değerlerinin planer görüntülere göre ileri düzeyde yüksek olduğu belirlendi.

Sonuç: En iyi lezyon detektabilitesinin SPECT veya SPECT/BT(AC) görüntüleme teknikleri ile sağlanabileceği belirlenmiştir.

Anahtar sözcükler: Sintigrafik görüntüleme, SPECT, SPECT/BT, Görüntü kalitesi, Kontrast gürültü oranı 


\section{INTRODUCTION}

The diagnostic interpretation from scintigraphic images acheived by gamma camera are closely related to the image quality aspects. In highcontrast scintigraphic images, the observer can easily distinguish lesions within natural background from surrounding tissues, and predict tumor size and location with high accuracy. However, most scintigraphic images may suffer from certain level of noise and low contrast. Overall, low-contrast images might impact the diagnostic accuracy and the lesions detectability [1].

In planar scintigraphy, the difference in the radiopharmaceutical uptake between tumor and surrounding healthy tissue is the key factor of image contrast. Tumor to background (T / B) ratio was found to be between 1: 1 and >10: 1 depending on the imaging time after radioiodine administration in thyroid cancer ${ }^{[2]}$. Consistent with a study conducted by Erdi, the lesions with volume less than $1 \mathrm{~cm}^{3}$ were not detected in planer and SPECT systems with T/B ratio as high as $10: 1$. While those lesion with volume $\geq 5.8$ $\mathrm{cm} 3$ were seen on static and SPECT images with $\mathrm{T} / \mathrm{B}$ ratio $^{[2]}$.

One of the image quality limitations is the fluctuation in the detector response to the peak energy in gamma camera. Full Width at Half Maximum (FWHM) is used to measure the spatial reolution in which lesions smaller than twice this value are expected to be undisplayed in scintigraphy. Hence, any lesion with radiopharmaceutical uptake is assumed to be detectable with least diameter of $\approx 1 \mathrm{~cm}$ in gamma camera images ${ }^{[3]}$.

Additionally, other factors including the activity concentration have also great impact on the lesion appearance. High activity accumulation increases the detection power of small-scale hyperactive lesions in case of low background activity, and thus improving the diagnostic accuracy.

Planer I-131 scintigraphy is conventionally used for monitoring and staging differentiated thyroid cancers. Planer whole body scintigraphy is still used in nuclear medicine centers after thyroidectomy and / or radioiodine ablation. The use of SPECT/CT hybrid imaging has started besides planer imaging in many investigations. Investigations should be made for more accurate localization and characterization of the lesion with low-intensity activity uptake detected in planar scintigraphy ${ }^{[4]}$.
Determination of the lower limit of lesions detectability is particularly important in order to provide high diagnostic accuracy in routine clinical trials. This value depends on several parameters including, Lesion-background (T/B) ratio $^{[5,6]}$,Used radionuclide ${ }^{[7,8,9]}$, Depth and location of tumor ${ }^{[10]}$, Total counts in image ${ }^{[6]}$, Features of gamma camera imaging system $^{[11]}$,Image processing algorithms for reconstruction, algorithm, filters, interrupts etc. ${ }^{[12]}$

Comprehensive analysis has been made on the factors affecting lesion detectability in literature ${ }^{[4,5,10]}$. In general, the golden standard for determining whether a nodule is detectable is the Contrast-Noise Ratio (CNR). A threshold value is used for the interpretation of the CNR. The CNR threshold, commonly defined by Rose criteria, was reported as low as $3-5^{[13]}$.

Currently, a phantom was designed in accordance with previous clinical studies to determine the lesion detectability in planar, SPECT and SPECT / CT scintigraphic images. The aim of the study was to evaluate the contrast $(\mathrm{C})$ and contrast to noise ratio (CNR) of the lesions with an equal volume and different concentrations of activity.

\section{MATERIALS AND METHODS}

\section{Phantom}

The phantom used in the experiments was made up of plexiglass material (intensity $1.15 \mathrm{~g} / \mathrm{cm}^{3}$ ). 4 holes were drilled in the phantom on a plate measuring $12 \times 5 \times 1 \mathrm{~cm}$ in size for $1 \mathrm{~cm}$ diameter test tubes. The distances between the holes were kept equal as $1.5 \mathrm{~cm}$. The plates on which the tubes were located were fixed $3 \mathrm{~cm}$ depth from the surface on two legs. The phantom design and the placement of the tubes are shown in Figure 1.

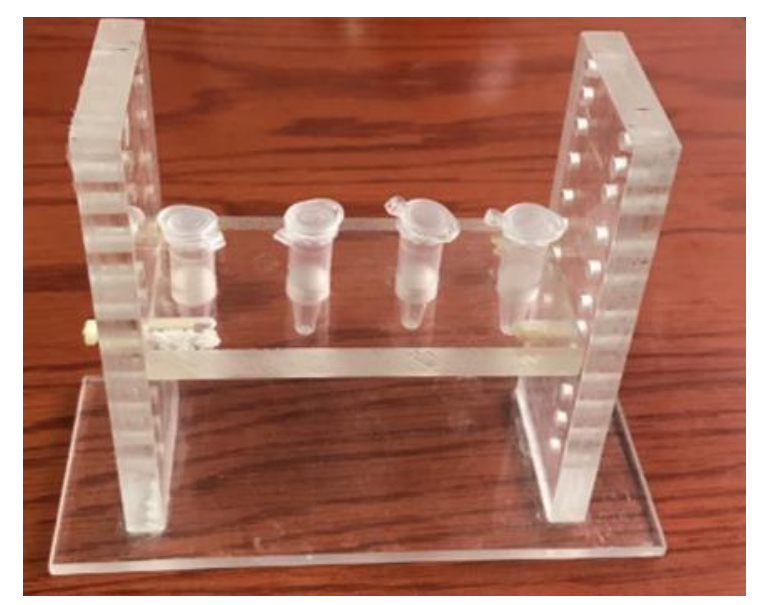

Figure 1. Phantom and simulated lesions (tubes). 
With regard to the routine patient protocol in our clinic, approximately $1.85 \mathrm{MBq}(50 \mu \mathrm{Ci})$ of 131I radionuclide is orally administered to patients for residual tissue and thyroid uptake test after totalthyroidectomy. For simulating lesions in patient, the amount of activity in the tubes was filled by $0.5 \mu \mathrm{Ci}, 1 \mu \mathrm{Ci}, 1.5 \mu \mathrm{Ci}$ and $2 \mu \mathrm{Ci}$ in order of $1 \%, 2 \%, 3 \%$ and $4 \%$ uptake, respectively ${ }^{[14]}$. These activity amounts were set equal to $1 \mathrm{ml}$ in tubes. The phantom was placed in a 2 liter waterfilled plastic tank to mimic the neck back ground activity. A homogenous mixture (concentration $0.25 \mu \mathrm{Ci} / \mathrm{ml}$ ) was provided by placing $0.5 \mu \mathrm{Ci}$ $131 \mathrm{I}$ in the water tank.

\section{Gamma Cameras and Scintigraphy Acquisition Parameters}

Planar scintigraphy imaging of this study was performed on two separate gamma cameras. One of these is Mediso Nucline TH22 Small Field Of View (SFOV) and the other gamma camera is Siemens Symbia T6 model with Large Field Of View (LFOV). Tomographic acquisitions were performed with two separate techniques. SPECT (SPECT No-AC) without attenuation correction was performed with Siemens Symbia T6 model Large Field Of View (LFOV) gamma camera. The last tomographic acquisition was SPECT/CT (AC) with attenuation correction. All planar and tomographic acquisitions were performed with high energy collimator. Planar images were acquised over $256 \times 256$ matrix, $364 \mathrm{keV}$ energy peak with $20 \%$ window range and 50,000 counts.

Phantom and tubes placed vertically to detectors. The tomographic acquisitions were completed at
$364 \mathrm{keV}$ energy peak, $20 \%$ window width, 128x128 matrix, $20 \mathrm{sec} /$ projection and 64 projections. Triple energy window was used for image scatter correction. Then, the counts recorded in the down and upper scatter windows were subtracted from the counts recorded in the main peak and finally a scatter corrected image is generated.

The phantom CT images were completed with the Siemens Symbia T6 model SPECT / BT device with $120 \mathrm{kV}, 20 \mathrm{~mA}$ values. Image attenuation correction (AC) was used for image processing. SPECT / CT images were obtained by fusing the SPECT and CT images with the routine imaging program of the system. 3D OSEM algorithm 10i $8 \mathrm{~s}, 9 \mathrm{~mm}$ Gauss filter was applied to image processing.

\section{Image Quantification and ROI analysis}

$\mathrm{C}$ and CNR calculations of the lesions were performed for quantitation of scintigraphic images. Equation (1) was used in C measurement ${ }^{15]}$.

$$
\mathrm{C}=\frac{\| \mathrm{M}_{\mathrm{L}}-\mathrm{M}_{\mathrm{BG}} \mid}{\mathrm{M}_{\mathrm{BG}}}
$$

$\mathrm{M}_{\mathrm{L}}=$ Mean count per pixel in lesion, $\mathrm{M}_{\mathrm{BG}}=$ Mean count per pixel in background tissue. Equation (2) was used in CNR calculations.

$$
\mathrm{CNR}=\mathrm{C} * \sqrt{\mathrm{N}_{0}}
$$

\section{C: Lesion contrast, $\mathrm{N}_{0}$ : Background counts.}

Images of lesions with four different techniques are as in Figure 2.

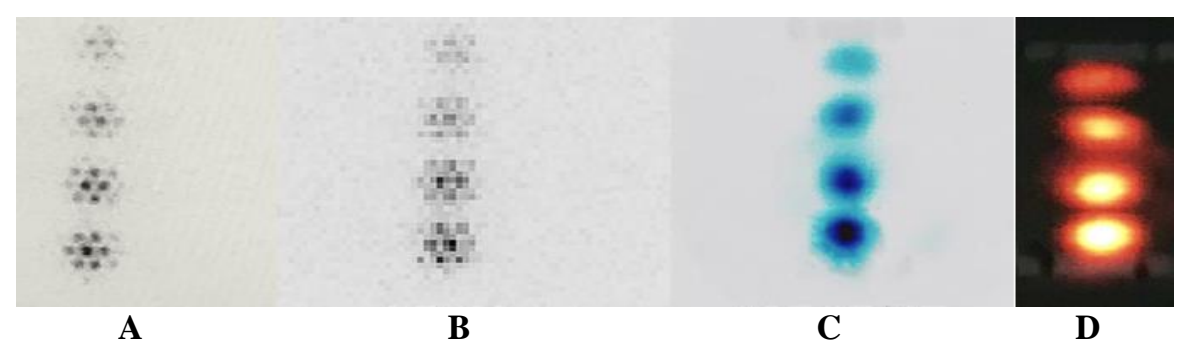

Figure2. (A) SFOV, (B) LFOV (C) SPECT and (D) SPECT / BT scintigraphic images of gamma cameras.

Analysis of SFOV images was done via the drawn areas of ROI on medical images at the Mediso Interview XP Workstation and quantified.

Planer images that acquised for analysis of LFOV images were transferred to imageJ software. The tools in that software were used in image analysis.
Analysis of SPECT and SPECT / CT tomographic images were performed using Siemens E-soft software.

The ROI boundaries were matched with the area where the activity was observed by selecting the diameter of the tubes. Background regions were determined with the help of ROIs drawn to the 
right and left of each activity zone. The drawn ROI's avarage counts, pixel values, etc. were taken from the software and recorded in the database.

Microsoft Excel sheet was used in the analysis. The average count and pixel values of each lesion and background ROIs were recorded on the sheet. $\mathrm{C}$ and $\mathrm{CNR}$ values were measured using these data.

\section{RESULTS}

Activity concentrations, uptake ratios and mean ROI values determined for each image were given in Table 1. Similarly, activity value per milliliter and ROI counts for the background were included in the table.

Table 1. ROI counts determined in SFOV, LFOV, SPECT and SPECT/CT (with AC) imaging systems at different uptake values of $50 \mu \mathrm{Ci}$ I-131 activity.

\begin{tabular}{lllllc}
\hline & & \multicolumn{4}{c}{ Mean ROI Counts } \\
\cline { 3 - 6 } Uptake(\%) & $\mu \mathrm{Ci} / \mathrm{ml}$ & SFOV & LFOV & SPECT & SPECT/BT (AC) \\
\hline$\% 1$ & 0.5 & 5 & 18 & 44.89 & 102.45 \\
$\% 2$ & 1 & 9 & 26 & 49.44 & 147.6 \\
$\% 3$ & 1.5 & 13 & 42 & 72.07 & 178.95 \\
$\% 4$ & 2 & 16.09 & 49 & 103.26 & 190.41 \\
BG & 0.00025 & 0.9 & 1.76 & 1.04 & 4.35 \\
\hline
\end{tabular}

The scintigraphic images obtained by four different imaging methods were saved to the workstations and quantified. $\mathrm{C}$ and CNR values were calculated and the obtained Data from the digital images are given in Table 3 and Table 4.

Table 2. Contrast values obtained from SFOV, LFOV, SPECT and SPECT/CT (with AC) images in response to $50 \mu \mathrm{Ci}$ I-131 activity.

\begin{tabular}{lllllc}
\hline & & \multicolumn{3}{c}{ Contrast } \\
\cline { 3 - 6 } Uptake $(\%)$ & $\mu \mathrm{Ci} / \mathrm{ml}$ & SFOV & LFOV & SPECT & SPECT/BT (AC) \\
\hline$\% 1$ & 0.5 & 4.76 & 9.3 & 41.95 & 22.52 \\
$\% 2$ & 1 & 8.6 & 13.69 & 46.3 & 32.87 \\
$\% 3$ & 1.5 & 13.32 & 22.83 & 67.95 & 40.07 \\
$\% 4$ & 2 & 16.71 & 26.57 & 97.78 & 42.7 \\
\hline
\end{tabular}

Table 3. CNR values obtained from SFOV, LFOV, SPECT and SPECT/CT (with AC) images in response to $50 \mu \mathrm{Ci}$ I131 activity.

\begin{tabular}{lllllc}
\hline & & \multicolumn{3}{c}{ CNR } \\
\cline { 3 - 6 } Uptake $(\%)$ & $\mu \mathrm{Ci} / \mathrm{ml}$ & SFOV & LFOV & SPECT & SPECT/BT (AC) \\
\hline$\% 1$ & 0.5 & 4.4 & 11.7 & 154.3 & 177.35 \\
$\% 2$ & 1 & 7.93 & 17.22 & 220.32 & 269.47 \\
$\% 3$ & 1.5 & 12.29 & 28.72 & 366.22 & 375.01 \\
$\% 4$ & 2 & 15.42 & 33.41 & 425.23 & 429.06 \\
\hline
\end{tabular}

When the ROIs were placed in the center of each lesion, the lowest count was observed in the smallest activity lesion and the highest count was in the lesion with the largest activity. In the same way, the calculated contrast values were also found to change proportionally with the ROIs counts. In contrast, the contrasts of lesions containing $2 \mu \mathrm{Ci}, 1.5 \mu \mathrm{Ci}, 1 \mu \mathrm{Ci}$, and $0.5 \mu \mathrm{Ci}$ in the SFOV gamma camera; were determined as $16.09,13.012,8.6$ and 5.238 respectively. Additionally, the contrast values in LFOV gamma camera obtained by SPECT/BT (with AC) and SPECT were noted as 26.57, 22.83, 13.69, 9.3; 
42.7, 40, 32.87, 22.51; and 97.7, 67.95, 46.3, 41.95 respectively (Figure 3 ).

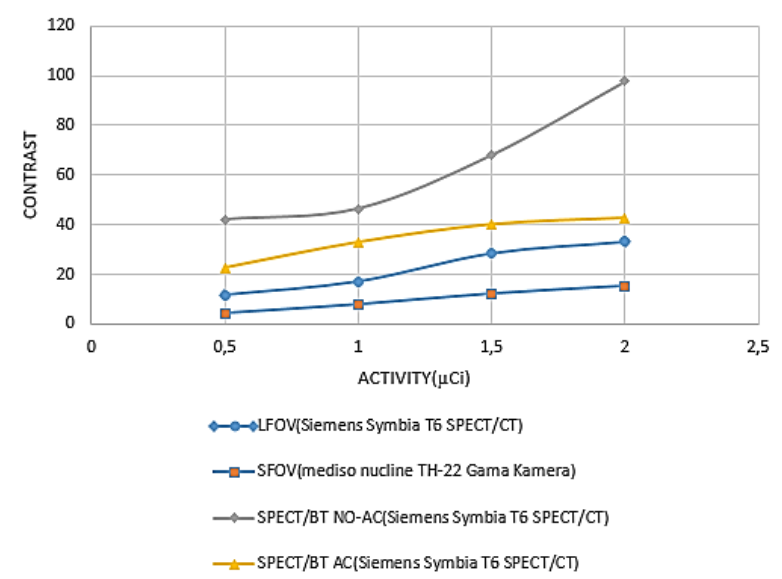

Figure 3. Activity versus contrast.

Likewise, CNR values increased as the size of the lesion increased. In the SFOV gamma camera; CNR values of lesions with $2 \mu \mathrm{Ci}, 1.5 \mu \mathrm{Ci}, 1 \mu \mathrm{Ci}$, and $0.5 \mu \mathrm{Ci}$ activities were as follows; 15.4, $12.29,7.93,4.39$. In the LFOV gamma camera image; these values are 33.4, 28.7, 17.21, 11.7. Besides, in the SPECT image with no attenuation correction, the values of $425.22,336,220.32$, 154.34 were found. While, with applied attenuation correction in SPECT/BT image; these values became larger follows; 429.05, $375,269.47,177.34$ as the highest values (Figure 4).

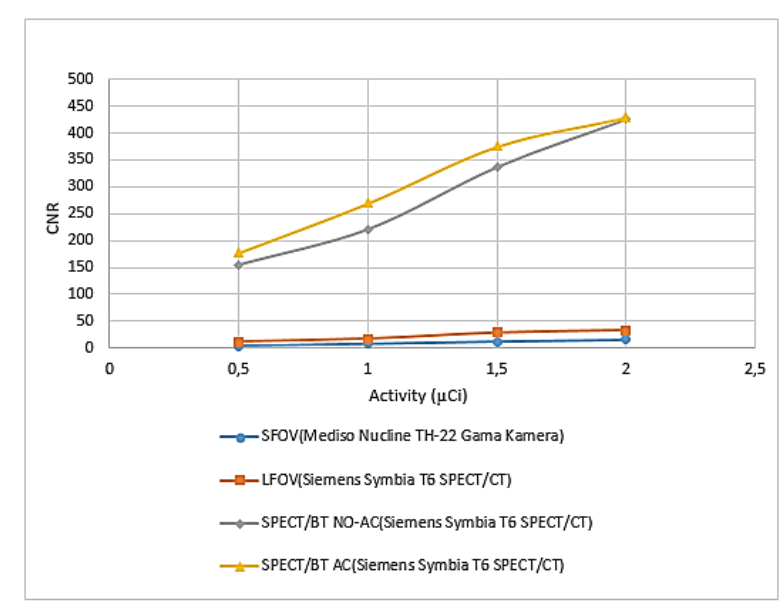

Figure 4. Activity versus contrast noise ratio (CNR).

\section{DISCUSSION}

In this study, the scintigraphy images obtained by SFOV, LFOV, SPECT and SPECT/CT (AC) techniques in these gamma cameras showed that contrast and CNR values increased as the mean number of counts increased in the lesions. Usually, image quality is affected by several parameters in routine imaging. For instance, oral administration of $50 \mu \mathrm{Ci} \mathrm{I}-131$ is routinely followed by 24 hours thyroid scintigraphy. The generated image is influenced by parameters of lesion/background (T / B) ratio owing to the depth and place of tumor for each patient, the type of radionuclide and image settings, the total number of counts in the image and the reconstruction algorithm, filters,. etc. Imaging protocols are mostly standardized by the providing company but investigations are required to enhance and improved the installed protocoles for better lesion detectability.

In a study by Bugby et al., it was concluded that SPECT/CT imaging improved the diagnostic accuracy in compared to planar imaging via clinical studies ${ }^{[15]}$. This can be explained by the superior characterization and localization of the I131 uptake of 3D SPECT/CT; moreover, a gamma camera with larger detection area leads to higher counting capacity ${ }^{[16]}$. When the sensitivities of the devices are compared: The sensitivity is $\geq 240$ $\mathrm{cpm} / \mu \mathrm{Ci}$ for SFOV gamma camera and $\geq 330$ $\mathrm{cpm} / \mu \mathrm{Ci}$ for SPECT if the LEAP collimator is held at $10 \mathrm{~cm}^{[17,18]}$.

In Table 2, the contrast values of SPECT and SPECT/CT (with AC) images were shown higher than planar imaging by SFOV and LFOV gamma cameras. It was justified that the improved ratio could be caused by the multiple projections obtained with SPECT scans while high ratio of attenuated photones is existant in the planar imaging.

Figure 2 also shows that the CNRs of SPECT and SPECT/CT (with AC) are significantly higher than the planar images. It is observed that increase of the lesion activity concentration will not significantly increase the image quality.

In this study, it was deduced that lesions with $1 \%$, $2 \%, 3 \%$ and $4 \%$ uptake after administration of 50 $\mu \mathrm{Ci}$ I-131 are highly detectable in SPECT and SPECT/CT tomographic images. Besides, it was concluded that when activity concentrations increased in planar images, lesion contrast and CNR could be relatively increased. 


\section{CONCLUSION}

The results of the present study showed that the best lesion detectability might be achieved by SPECT or SPECT/CT (with AC) imaging techniques according to the Rose criteria. SPECT imaging method can be recommended to provide high levels of lesion detectability in centers without SPECT/CT systems.

\section{REFERENCES}

1. Goenka AH, Herts BR, Obuchowski NA, Primark AN, Dong F, Karim W, Baker ME. Effect of reduced radiation exposure and iterative reconstruction on detection of lowcontrast low-attenuation lesions in an anthropomorphic liver phantom: an 18-reader study. Radiology 2014; 1: 154-163

2. Erdi YE. Quantification of thyroid volume. Journal of Nuclear Medicine 1997; 6:1002.

3. Hamilton D. Single Photon Planar Imaging. In. Hamilton D, David I (Eds). Single Photon Planar Imaging Diagnostic Nuclear Medicine A Physics Perspective. 1st Edition. Berlin: Springer, 2004; pp 115-136.

4. Aliyev A, Metin H. Tiroit Kanserlerinde Tek Foton Emisyon Tomografisi/Bilgisayarl1 Tomografi Görüntüleme. Nuclear Medicine Seminars / Nükleer Tıp Seminerleri 2016; pp 21-30.

5. Rockoff SD, Goodenough DJ, McIntire KR. Theoretical limitations in the immunodiagnostic imaging of cancer with computed tomography and nuclear scanning. American Association for Cancer Research 1980; 8: 3054-3058.

6. Bradwell AR, Fairweather DS, Dykes PW, Keeling A, Vaughan A, Taylor J. Limiting factors in the localization of tumors with radiolabeled antibodies, Immunology Today 1985; 5:163-170.

7. Meikle SR, Dahlbom M. Positron emission tomography. In: Murray IPC., Ell PJ (Eds). Nuclear medicine in clinical diagnosis and treatment. New York: Churchill Livingston, 2006; pp 350-351.

8. Maurer AH, Caroline DF, Jadali FJ, Manzone TA, Maier WP, Au FC, Schnall SF. Limitations of craniocaudal thallium-201 and technetium-99m-sestamibi

mammoscintigraphy, Journal of Nuclear Medicine 1995; 9:1696-1700.

9. Weber W, Bartenstein P, Gross MW, Kinzel GD, Daschner H, Feldmann HJ, Reidel G., Ziegler SI, Lumenta C, Molls M, Schwaiger M. Flourine-18-FDG PET and Iodine-123IMT SPECT in the evaluation of brain tumors, Journal of Nuclear Medicine 1997; 5:802-808.

10. Erdi AK, Erdi YE, Yorke ED, Wessels BW. Treatment planning for radioimmunotherapy, Physics in Medicine and Biology 1996; 10:2009-2026.

11. Goodenough DJ, Atkins FB. Theoretical limitations of tumor imaging. In: Srivastava S(Eds). Radiolabeled monoclonal antibodies for imaging and therapy, New York: Plenum Publishing Corporation, 1998; pp 152-155.

12. Jaszczak RJ, Coleman RE, Whitehead FR. Physical factors affecting quantitative measurements using camera-based single photon emission computed tomography, IEEE Nuclear and Plasma Sciences Society 1981; 1:69-80.

13. Rose A. The visual process. In: Rose A(Eds).Vision: Human and Electronics. 1st ed. New York: Plenum Press, 1973; pp 1-27.

14. Schneider DF, Ojomo KA, Chen H, Sippel RS. Remnant Uptake as a Postoperative Oncologic Quality Indicator. Thyroid 2013; 10:1269-1276.

15. Bugby SL, Lees JE, Ng AH, Alqahtani MS, Perkins AC. Investigation of an SFOV hybrid gamma camera for thyroid imaging. Physica Medica 2016; 1: 290-296.

16. Hassan FU, Mohan FK. Clinical Utility of SPECT/CT Imaging Post-Radioiodine Therapy: Does It Enhance Patient Management in Thyroid Cancer?, European Thyroid Journal 2015; 4:239-245.

17. https://www.healthcare.siemens.com.au/mole cular-imaging/spect-and-spect-ct/symbia-t. Retrieved January 2, 2019. 
18. http://santaxweb.dk/wpcontent/uploads/2016/08/THB_1014_web.pd f. Retrieved January 2, 2019. 